\title{
The commercial potential of forest trees as medicinal and health ingredients
}

\author{
SYAMSUL HIDAYAT ${ }^{1,2, \bullet}$, ERVIZAL A.M. ZUHUD ${ }^{1, \bullet \bullet}$, DIDIK WIDYATMOKO ${ }^{2}$, BAHRUNI ${ }^{3}$, \\ IRMANIDA BATUBARA ${ }^{4}$ \\ ${ }^{1}$ Department of Conservation Forest Resources \& Ecotourism, Faculty of Forestry and Environment, Institut Pertanian Bogor. \\ Jl. Ulin Lingkar Akademik, Kampus IPB Dramaga, Bogor 16680, West Java, Indonesia. Tel./fax.:+62-251-8626806, \\ "email: syamsul_krb@apps.ipb.ac.id; •veamzuhud@apps.ipb.ac.id \\ ${ }^{2}$ Research Center for Plant Conservation and Botanic Gardens, Indonesian Institute of Sciences. Jl. Ir. H. Juanda No. 13, Bogor16122, West Java, Indonesia \\ ${ }^{3}$ Department of Forest Management, Faculty of Forestry and Environment, Institut Pertanian Bogor. Jl. Ulin Lingkar Akademik, Kampus IPB Dramaga, \\ Bogor 16680, West Java, Indonesia \\ ${ }^{4}$ Department of Chemistry, Faculty of Mathematics and Natural Sciences, Institut Pertanian Bogor. Jl. Agatis, Kampus IPB Dramaga, Bogor 16680, West \\ Java, Indonesia
}

Manuscript received: 24 May 2021. Revision accepted: 20 June 2021.

\begin{abstract}
Hidayat S, Zuhud EAM, Widyatmoko D, Bahruni, Batubara I. 2021. The commercial potential of forest trees as medicinal and health ingredients. Biodiversitas 22: 2795-2804. Indonesian forests contain many trees that belong to medicinal plants classified as nontimber forest products (NTFP). Although these plants have been used from generation to generation by several ethnic groups and even some of them have become commercial goods, many species have not received special attention in terms of their cultivation. This study aimed to explore the commercial value of forest trees as medicinal ingredients and obtain a recommended ranking for their cultivation. The method used was market surveys to herbal stores and questionnaires to experts related to medicinal plants. The results showed that there are 59 species of forest trees used as medicinal ingredients and health supplements. Cinnamomum burmanni, Morinda citrifolia, and Moringa oleifera have the most diverse commercial products in drugs and health stores. These three species also have active ingredients that potentially substitute for chemical drugs. Following the advice of medicinal plant experts, these three species are also included in the ten species recommended for immediate cultivation.
\end{abstract}

Keywords: commercial, cultivation, forest trees, medicinal ingredients

\section{INTRODUCTION}

Based on the Central Bureau of Statistics or BPS (2020) data, $58-85 \%$ of the Indonesian population in each province were self-medication using traditional medicines. The community in general applies traditional medicine for reasons that are easy, cheap, and effective. Traditional medicine practices in Indonesia mostly use wild plants. Ethnic communities in rural areas have a very close life with forest resources, they are therefore very dependent on the existence of forests, among which is the use of forest plants for medicine and health. Medicinal plants significantly contribute to affordable healthcare and livelihood security, making them one of the most valuable non-timber forest products (NTFP) (Astutik et al. 2019)

Many of the medicinal plants from the forest are tree habitus, which in general also function as timber production. In general, these plants are harvested naturally and have been used for hundreds of years from generation to generation without paying attention to their cultivation efforts. On the other hand, the exploitation of medicinal plants for commercial needs is increasing, medicinal plants as raw materials are turned into marketable goods with monetary or exchange value (Nugroho et al. 2016). Some of the medicinal plant species are starting to decrease in quantity and even lose their habitat. The extensive decline of medicinal plants from the wild and continuous habitat loss has led to the shortage number of medicinal plants (El- shabasy 2017). Forest degradation and habitat destruction are major causes of the loss of medicinal plant resources (Chen et al. 2016), while research on medicinal plant cultivation is still very limited. This situation reminds many parties to immediately carry out conservation efforts through cultivation activities. With the fact that many wild medicinal species are being over-exploited, some agencies recommend that wild species be brought into domestication (Schipmann et al. 2006).

Conservation of medicinal plants can be done by encouraging people not to cut down the trees and encouraging them to plant fast-growing native trees for their domestic needs (Kadam and Pawar 2020). Cahyaningsih (2021) stated that medicinal plants can be used sustainably, as long as all stakeholders commit to maintaining them, and this can be started from propagation or cultivation studies. Moreover, increased cultivation contributes to decreasing the harvest volume of medicinal plants, benefits the recovery of their wild resources, and decreases their prices to a more reasonable range (Chen et al. 2016).

On the other hand, the development of media and information technology has made it easy for everyone to access their needs, including medical needs using medicinal plants. Currently, many medicines and health supplements, made from wild and cultivated plants, are traded in conventional and online markets, the products are in raw and processed form. Kuniyal et al. (2013) stated that information on the marketing of plant species will be useful 
for understanding the current trends in availability and prices. The information will also be useful in the development of appropriate added value methods, setting of cultivation priorities, and determining sustainable harvesting strategies. This study aims to determine the recommended forest trees medicinal plant species for cultivation and to reveal their commercial potential as medicinal ingredients and health supplements on the market.

\section{MATERIALS AND METHODS}

\section{Study area}

The study has been conducted in Bogor, Kuningan, and Sukabumi, West Java Province, in July-December 2020. Previous ethnobotanical studies in 28 ethnic residents around Indonesian forest areas have been reviewed. Such studies were conducted between the years 2000 and 2019.

\section{Research materials}

The materials of this study were medicinal products and health supplements, found in medicinal/herbal stores and online shops. As a support for the study, we used the results of previous ethnobotanical studies and a set of questionnaires.

\section{Data collection}

Market surveys were conducted either directly to herbal stores or online shops that sell medicinal ingredients. In this study, 20 stores or shops were used as a sampling, consisting of ten conventional stores and ten online shops. This survey was intended to obtain information about tree species that are part of a medicine or health supplement ingredient, and commercial products from medicinal plants and their uses. Information was also searched online regarding the phytochemical and nutritional contents of selected medicinal plant species. After that, we decided which medicinal plants are recommended for cultivation, and built an opinion of the value of the species to compensate for conservation efforts, a brief discussion, and a questionnaire were held involving 12 medicinal plant experts.

Information on medicinal plants and their uses, obtained from the results of previous ethnobotanical studies, were used as supporting data related to information on medicinal plants used by the community, and then plant species are selected, and included in the NTFPs group. Plant species belong to NTFPs based on Minister of Forestry Regulation No.p.35 / menhut-ii / 2007 concerning Non-Timber Forest Products (NTFPs).

\section{Data analysis}

The market survey results were tabulated into one information as a list of medicinal plants included in the NTFPs group. This list was supported by information on the use and content of phytochemicals and nutrients based on the results of the survey literature. Meanwhile, the results of the questionnaire have been processed using the Eckenrode method (Fadhil and Nurba 2019) and tabulated in Table 1 to obtain a ranking of species recommended for cultivation.
Table 1. Calculation of the Eckenrode method for cultivation of recommended species

\begin{tabular}{lllllllll}
\hline Species & $\mathbf{R}_{\mathbf{1}}$ & $\mathbf{R}_{\mathbf{2}}$ & $\mathbf{R}_{\mathbf{3}}$ &. & $\mathbf{R j}$ &. & $\mathbf{R}_{\mathbf{n}}$ & Score \\
\hline Sp1 & P11 & P12 & P13 & $\ldots$. & $\ldots$. & $\ldots$. & P1n & Nsp1 \\
Sp2 & P21 & P22 & P23 & $\ldots$ & $\ldots$. & $\ldots$. & P2n & Nsp2 \\
Sp3 & P31 & P32 & P33 & $\ldots$ & $\ldots$. & $\ldots$. & P3n & $\ldots .$. \\
Spi & $\ldots$. & $\ldots$ & $\ldots$ & & Pij & & $\ldots \ldots$ & $\ldots$. \\
Spn & & & & & & & & \\
$\begin{array}{l}\text { Multiplier } \\
\text { factor }\end{array}$ & $\mathrm{R}_{\mathrm{n}-1}$ & $\mathrm{R}_{\mathrm{n}-2}$ & $\mathrm{R}_{\mathrm{n}-3}$ & $\ldots$. & $\mathrm{R}_{\mathrm{n}-\mathrm{j}}$ & $\ldots$. & $\mathrm{R}_{\mathrm{n}-\mathrm{n}}$ & $\mathrm{N}_{\text {Total }}$ \\
\hline
\end{tabular}

Where:

$\mathrm{Rj} \quad=\mathrm{j}$-rank in sequence, $\mathrm{j}=1,2,3, \ldots \ldots, \mathrm{n}$.

Spi $=$ species, $\mathrm{i}=1,2,3, \ldots \ldots, \mathrm{n}$.

$\mathrm{P}_{\mathrm{ij}} \quad$ = Number of respondents who chose $\mathrm{j}$, for 'Spi'

$R_{n-j}=$ Multiplier factor of $j$, which is obtained by reducing the number of spesies (n)

Score $=\sum\left(\mathrm{P}_{\mathrm{ij}} \times \mathrm{R}_{\mathrm{n}-\mathrm{j}}\right)$

Qualification based on the scores in Table 1, as follows:

Rank 1-15 : very high recommendation

Rank 16-30 : high recommendation

Rank 31-45 : moderate recommendation

Rank 46-59 : low recommendation

To calculate the commercial prospects and the need for the number of individual trees from the selected medicinal plants, it was analyzed using the potential for bioprospection of their chemical content. The main chemical substances contained in plant species are equivalent to the chemicals needed to produce a type of drug used for the disease.

An example of the calculation is as follows: for example, to make one tablet it takes as much as B gr of substance $\mathrm{A}$ and an individual tree produces $\mathrm{C}$ gr of substance $\mathrm{A}$, then one individual tree will produce $(\mathrm{C}: \mathrm{B})=$ $\mathrm{Y}$ tablet. If the price per tablet is IDR N, then economically the value of one tree is IDR $(\mathrm{N} x \mathrm{Y})$.

\section{RESULTS AND DISCUSSION}

\section{Forest medicinal plants recommended for cultivation}

In total, there were 59 species of NTFPs (Table 2) recorded in the composition of the drug ingredients, which were commonly used in medical practice for the ten most common diseases in the community based on ethnobotanical data. The ten most common diseases treated using forest medicinal plants were diarrhea, cough, malaria, toothache, itchy, low back pain, sprue, hepatitis, rheumatism, and gastritis.

Based on data processing results from questionnaires filled by the experts, ten NTFP tree species that occupy the highest position are recommended for immediate cultivation (Table 3 ). The highest position was occupied by Moringa oleifera or kelor. The species is a medicinal plant that contains lots of vitamins and is effective for malnutrition. This medicinal plant can be used to increase the body's immunity (Circular of the Director-General of Health Services. 2020) so that it is appropriate to get the highest recommendation for cultivation. 
Table 2. Status and Use of NTFPs for medicinal purposes in forest communities recorded on the composition of a commercial drug

\begin{tabular}{|c|c|c|c|c|}
\hline Scientific names & Local names & $\begin{array}{l}\text { Conservation } \\
\text { status } \\
\text { (IUCN 2020) }\end{array}$ & $\begin{array}{c}\text { Number of } \\
\text { ethnic users } \\
\# \\
\end{array}$ & Medicinal uses \\
\hline Adenanthera pavonina $\mathrm{L}$. & Saga pohon & Lc & 2 & Fever \\
\hline Aleurites moluccanus (L.)Willd. & Kemiri & $\mathrm{Lc}$ & 2 & Sprue \\
\hline Alstonia angustifolia Wall. ex A.DC. & Pule hitam & Lc & 1 & Malaria \\
\hline Alstonia scholaris (L.) R. Br. & Pule & Lc & 12 & Malaria \\
\hline Altingia excelsa Noronha & Rasamala & Lc & 1 & Diarrhea \\
\hline Areca catechu $\mathrm{L}$. & Pinang & Rare* & 6 & Toothache \\
\hline Arenga pinnata (Wurmb) Merr. & Aren & - & 3 & Wound \\
\hline Artocarpus altilis (Parkinson ex F.A.Zorn) Fosberg & Sukun & - & 2 & Liver \\
\hline Artocarpus elasticus Reinw. ex Blume & Terep & Lc & 1 & Low back pain \\
\hline Artocarpus heterophylla Lam. & Nangka & - & 1 & Stomach ache \\
\hline Averrhoa bilimbi L. & Belimbing wuluh & - & 6 & Cough \\
\hline Azadirachta indica A.Juss. & Mimba & $\mathrm{Lc}$ & 3 & Malaria \\
\hline Baccaurea racemosa (Reinw. ex Blume) Müll.Arg. & Menteng & - & 1 & Rheumatism \\
\hline Barringtonia acutangula (L.) Gaertn. & Bitung & $\mathrm{Vu}$ & 1 & Itchy \\
\hline Bischofia javanica Blume & Gintungan & $\mathrm{Lc}$ & 1 & Cough \\
\hline Bixa orellana $\mathrm{L}$. & Kesumba & Lc & 1 & Stomach ache \\
\hline Caesalpinia sappan $\mathrm{L}$. & Secang & Lc, rare* & 4 & Sprue \\
\hline Calophyllum inophyllum $\mathrm{L}$. & Nyamplung & $\mathrm{Lc}$ & 2 & Cough \\
\hline Cananga odorata (Lam.) Hook.f. \& Thomson & Kenanga & Lc & 1 & Hypertension \\
\hline Cinnamomum burmanni (Nees \& T.Nees) Blume & Kayu manis & - & 2 & Low back pain \\
\hline Cinnamomum sintoc Blume & Sintok & Lc, rare* & 2 & Low back pain \\
\hline Corypha utan Lam. & Gebang & $\mathrm{Lc}$ & 1 & Malaria \\
\hline Cryptocarya massoy (Oken) Kosterm. & Masoi & NT, rare* & 1 & Asthma, cough \\
\hline Dimocarpus longan Lour. & Lengkeng & NT & 1 & Diarrhea \\
\hline Elaeocarpus grandiflorus $\mathrm{Sm}$. & Rejasa & - & 1 & Low back pain \\
\hline Elaeocarpus serratus L. & Genitri & - & 2 & Sprue \\
\hline Eusideroxylon zwageri Teijsm. \& Binn. & Ulin & $\mathrm{Vu}$ & 2 & Low back pain \\
\hline Garcinia mangostana $\mathrm{L}$. & Manggis & - & 1 & Diarrhea \\
\hline Gardenia augusta (L.) Merr. & Kaca piring & - & 2 & Sprue \\
\hline Gnetum gnemon L. & Melinjo & $\mathrm{Lc}$ & 1 & Sprue \\
\hline Guazuma ulmifolia Lamk. & Jati belanda & $\mathrm{Lc}$ & 1 & Slimming \\
\hline Hibiscus elatus $\mathrm{Sw}$. & Waru & Lc & 7 & Fever \\
\hline Lagerstroemia speciosa (L.) Pers. & Bungur & - & 3 & Diabetes \\
\hline Lansium parasiticum (Osbeck) K.C.Sahni \& Bennet & Duku & - & 4 & Malaria \\
\hline Magnolia champaca (L.) Baill. ex Pierre & Cempaka & $\mathrm{Lc}$ & 2 & Low back pain \\
\hline Mangifera indica $\mathrm{L}$. & Mangga & $\mathrm{DD}$ & 2 & Diarrhea \\
\hline Manilkara zapota (L.) P.Royen & Sawo & - & 4 & Diarrhea \\
\hline Melaleuca leucadendra (L.) L. & Kayu putih & - & 3 & Rheumatism, itching \\
\hline Morinda citrifolia $\mathrm{L}$. & Mengkudu & - & 11 & Gastritis \\
\hline Moringa oleifera Lam. & Kelor & Rare* & 6 & Liver \\
\hline Myristica fragrans Houtt. & Pala & $\mathrm{DD}$ & 2 & Stomach ache \\
\hline Pangium edule Reinw. & Kluwek & Rare* & 1 & Skin disease \\
\hline Parkia timoriana (DC) Merr. & Kedawung & Lc, rare* & 2 & Stomach ache \\
\hline Peltophorum pterocarpum (DC.) K.Heyn & Soga & - & 1 & Stomach ache \\
\hline Peronema canescens Jack & Sungkai & Lc & 1 & Malaria \\
\hline Phyllanthus acidus (L.) Skeels & Cermai & - & 3 & Cough \\
\hline Pometia pinnata J.R.Forst. \& G.Forst. & Matoa & $\mathrm{Lc}$ & 1 & Diarrhea \\
\hline Pterocarpus indicus Willd & Angsana & En & 3 & Diabetes \\
\hline Pterospermum javanicum Jungh. & Bayur & Lc & 2 & Liver \\
\hline Santalum album $\mathrm{L}$. & Cendana & $\mathrm{Vu}$ & 1 & Dysentery \\
\hline Schleichera oleosa (Lour.) Merr. & Kesambi & $\mathrm{Lc}$ & 2 & Skin disease \\
\hline Stelechocarpus burahol (Blume) Hook.f. Thomson & Kepel & - & 1 & Skin smoother \\
\hline Sterculia foetida $\mathrm{L}$. & Kepuh & - & 3 & Urine laxative \\
\hline Swietenia macrophylla King & Mahoni daun besar & $\mathrm{Vu}$ & 2 & Malaria \\
\hline Swietenia mahagoni (L.) Jacq & Mahoni & NT & 1 & Malaria \\
\hline Syzygium cumini (L.) Skeels & Duwet & $\mathrm{Lc}$ & 2 & Diabetes \\
\hline Syzygium polyanthum (Wight) Walp. & Salam & - & 2 & Gout \\
\hline Tamarindus indica $\mathrm{L}$. & Asam jawa & Lc & 4 & Liver, diarrhea \\
\hline Terminalia catappa $\mathrm{L}$. & Ketapang & Lc & 4 & Toothache \\
\hline
\end{tabular}

Note: * based on IBSAP 2003, \# the number of ethnic users from 28 ethnicities surveyed 
Table 3. The ten highest forest medicinal plants recommended for cultivation

\begin{tabular}{llll}
\hline Scientific names & Local names & Score & Ranking \\
\hline Moringa oleifera Lam. & Kelor & 834 & 1 \\
Alstonia scholaris (L.) R. Br. & Pule & 827 & 2 \\
Areca catechu L. & Pinang & 812 & 3 \\
Aleurites moluccanus (L.) Willd. & Kemiri & 788 & 4 \\
Azadirachta indica A.Juss. & Mimba & 764 & 5 \\
Morinda citrifolia L. & Mengkudu & 755 & 6 \\
Alstonia angustifolia Wall. ex A.DC. & Pule hitam & 731 & 7 \\
Caesalpinia sappan L. & Secang & 708 & 8 \\
Cinnamomum burmanni (Nees \& T.Nees) Blume & Kayu manis & 695 & 9 \\
Cinnamomum sintoc Blume & Sintok & 677 & 10 \\
\hline
\end{tabular}

Cultivation of forest medicinal plants is essential as one of the real conservation efforts for sustainable use. Most medicinal plants are still collected from the wild; as human populations increase, as forests decline, and as areas of remaining wild habitats become locked into parks and reserves, people in some areas can no longer collect the plant materials they need (Schipmann et al. 2006). The use of medicinal plants by people living around the forest is rarely followed by efforts to replant these species (Nento and Tueno 2019), either by user groups or by other parties. This could be due to people's ignorance or because of some people who use medicinal plants do not understand certain medicinal plant cultivation techniques (Chapman and Chomchalow 2005; Malik et al. 2013; Chen et al.2016). As a consequence of people's ignorance of the regeneration of medicinal plants in the forest, it often brings disasters to the community's environment, even further detrimental to the country.

Meanwhile, the community's lack of understanding of the cultivation techniques can result in certain species being lost in their habitat for a certain period. So far, the cultivation of medicinal plants carried out by the Indonesian Ministry of Health and traditional medicinal companies is still focused on herbs, and a small part of shrubs, while medicinal plants with tree habitus are rarely given attention. Riptanti et al. (2018) stated that out of 283 species of medicinal plants recommended BPOM, only 13 species have been intensively cultivated by the Indonesian people, i.e. ginger (jahe), galangal (lengkuas), lesser galangal (kencur), turmeric (kunyit), bitter ginger (lempuyang), Javanese turmeric (temulawak), pink and blue ginger (temu ireng), glass splinter (keji beling), sweet grass (dringo), cardamom (kapulaga), fingerroot (temukunci), cheese fruit (mengkudu), and king of bitters (sambiloto). Almost all of them are a group of seasonal herbaceous plants. Based on Gabungan Pengusaha Jamu (GP Jamu) data in 2016, currently cultivated medicinal plants are only $22 \%$ of the total medicinal plant species traded in Indonesia and direct harvesting from the forest is $78 \%$.

Experts have stated that it is necessary to cultivate some potentially medicinal tree species. There are several different reasons for experts in determining the recommended species for cultivation among others, as follows:

\section{Herbs that have been scientifically tested}

One of the species that has been scientifically tested is Caesalpinia sappan with the main content of brazilin, which is a red dye that is antioxidant and hepatoprotective. Meanwhile, some other species, such as noni, eucalyptus, cinnamon, moringa, guava, gooseberry, bay leaf, neem, starfruit, have been recorded in the Formulary for Indonesian traditional medicinal herbs (Froti) in the Decree of the Minister of Health of the Republic of Indonesia number hk.01.07. / Menkes / 187/2017 concerning the formulary of Indonesian traditional medicinal herbs. The formulary contains information about some species of medicinal plants that grow in Indonesia which have been proven safe when used according to regulations and are empirically beneficial for maintaining health.

\section{Priority species of the Ministry of Health for research}

Morinda citrifolia and Cinnamomum burmanni are two species of 31 medicinal plants that focus on research and development in Indonesia. This is stated in the Regulation of the Minister of Health of the Republic of Indonesia number 88/2013 concerning the master plan for developing traditional medicinal raw materials.

\section{Commercial species possessing many uses but their cultivation is still limited}

Some medicinal plants have already been an export commodity that relied on as the country's foreign exchange, but their productivity is still not optimal due to limited cultivation activities. For example, nutmeg (Myristica fragrans) cultivation is still very limited, while farmers' knowledge of nutmeg cultivation techniques is still traditional. Likewise, sintok (Cinnamomum sintoc) is an economically valuable species, the existence of sintok needs to get attention and increase its population through cultivation (Ismail et al. 2019). The availability of applicable and feasible cultivation technology will encourage efficiency in increasing productivity and quality so that in addition to having an impact on increasing farmers' income, it will also increase the competitiveness of Indonesian nutmeg and sintok in the international market.

\section{Species with high added value}

Medicinal plants can have multiple functions, including ingredients for spices and herbs. An example is cinnamon 
(Cinnamomum burmanni) which is spread in almost all regions in Indonesia. The demand for cinnamon is increasing with the increasing number of parties who use cinnamon as an industrial raw material, both on a domestic and national scale. Cinnamon cultivation increases farmers' and the country's foreign exchange and can provide added value by creating various product variants such as syrup and cinnamon powder.

\section{People commonly use species without realizing their properties as antioxidants}

Some species of medicinal plants are close to people's daily lives. These plants are used both when people are sick and in good health, so these species are needed by people, especially in rural areas. An example is the areca nut (Areca catechu). In Indonesia, areca nut has been recognized as part of the 'sirih pinang' culture, especially in the eastern part of Indonesia. Without realizing it, areca nut is scientifically known as a source of vitamin $E$ and antioxidants, which are very beneficial for health.

\section{Indonesian native species and their cultivation techniques are well known}

Original Indonesian Herbal Medicines Formulary, hereinafter abbreviated as FOHAI, is a document containing a number of native Indonesian medicinal plants and information on their important uses. This is stated in the Regulation of the Minister of Health of the Republic of Indonesia number 6/2016 concerning the original Indonesian herbal medicine formulary. These native Indonesian medicinal plants include noni, cinnamon, bay leaf, blackboard tree, cashew, bay cedar, mangosteen, eucalyptus, nutmeg, and guava.

\section{Species contain essential oils that can increase the body's immunity}

Currently, plants that produce essential oils are being of concern to many parties in the face of the Covid-19 outbreak. Some species of 'kayu putih' are believed to have essential oils that can ward off viruses and provide immunity. An example is plants of the genus Melaleuca and Eucalyptus, which contain 1,8-cineol, is a natural monoterpene, also known as eucalyptol.

\section{Species having multiple uses}

Apart from being medicinal plants, plants recommended for cultivation are also expected to have many other benefits, for example as building materials, craft materials, or food alternatives. An example is the candlenut tree (Aleurites moluccanus), apart from being potential as a medicinal ingredient, the fruit is also used as a spice, and the wood has the potential as a building material.

\section{The commercial potential of forest medicinal plants}

Medicinal plants originating from forests are currently not receiving enough attention, but their potential is considered quite significant in terms of economic value, processing technology, and marketing (Syamsiah et al. 2016). Medicinal plants answer the need for access to medicine as a component of health services and the needs of increasing income for farmers and as a significant contribution to the national economy (Riptanti et al. 2018). The results of the recapitulation of medicinal plant species, some of which are species that already have commercial reputations both nationally and internationally, such as nutmeg and cinnamon. However, many potential species are only being used locally, such as moringa, secang, noni, starfruit, and breadfruit. These species still need a touch of serious cultivation and promotion in order to have high added values.

In order to support medicinal plants being promoted and their commercial potential developed, it is necessary to know the opinion of experts regarding the values of these species. Of the 59 NTFPs species, 10 species (Table 4) were selected as the highest value based on experts' opinions.

As shown in Table 4, the medicinal plants that have the most potential to be developed were Moringa oleifera. This plant has a high value and is in the first position in terms of cultivation recommendations. Kelor is also a species prioritized for research and development by the Ministry of Health $(\mathrm{MOH})$. Kelor is a local food that contains minerals, vitamins, and amino acids needed by pregnant and lactating mothers. Kelor leaves can also be processed into flour, processed into various types of functional food, for example, for making porridge for toddlers. Based on market surveys, whether it has been conducted directly in drug/herbal stores or online market surveys, kelor also has many medicinal uses. It is claimed to be used to treat 26 kinds of diseases/complaints with 24 kinds of commercial products on the market today.

Other species that are highly valued by experts and occupy the top 10 species recommended for immediate cultivation were candlenut (Aleurites moluccanus), noni (Morinda citrifolia), and cinnamon (Cinnamomum burmanni). Despite getting a high position for cultivation recommendation, Candlenut has not been included in the development priority by the Ministry of Health. Besides that, candlenut cultivation has been carried out in many areas. Zakaria et al. (2019) said that every year the area and production of candlenut plants in Indonesia tends to increase. The main cultivated areas in Indonesia are the provinces of North Sumatra, West Sumatra, South Sumatra, Bengkulu, Lampung, West Java, West Kalimantan, South Kalimantan, East Kalimantan, Bali, South Sulawesi, Maluku and East Nusa Tenggara.

Morinda citrifolia or noni is one of the plant species that is the concern of the Ministry of Health for research and development. Krishnakumar (2015) stated that the root, stem, bark, leaves, flowers, and fruits of the noni are all involved in various combinations in almost 40 known and recorded herbal remedies. Meanwhile, the survey results in this study found only 14 commercial forms of drugs that were sold for treating 28 types of diseases/complaints. This study showed that the form of noni commercial products in Indonesia is still lower than the study of Krisnakumar. Traditionally, noni fruit is used for gastritis treatment and as a source of probiotics. In recent years, the study on probiotic bacteria has been increased due to their beneficial 
effects on human health (Rahayuningsih et al. 2016). This is a good opportunity to increase the production of plants.

Cinnamomum burmanni or cinnamon is also one of the commodities prioritized by the Indonesian Ministry of Health for research and development. Based on the ethnobotanical study, the use of cinnamon by the local communities as a traditional medicinal ingredient is still limited to four ethnicities, i.e. South Kalimantan, Sumba, Flores, and Ternate. According to BAPPEBTI (2020), the demand for cinnamon from abroad is quite high, while national production has not increased significantly in recent years. In this study, the results of the market survey showed that people widely used cinnamon. The survey obtained eight forms of commercial products used for 18 kinds of diseases/complaints. This showed that both nationally and internationally cinnamon is needed by many people even though ethnically it is not widely known.

The results of a market survey on medicinal uses and a literature survey regarding their chemical and nutritional content showed that the ten species (Table 5) have the potential to be developed commercially.

Based on the use, chemical, and nutritional contents, this study supports the suggestion of expert respondents that these species (Table 5) have the potential to be cultivated and promoted as modern phyto-pharmacy ingredients. Based on all data above (cultivation recommended, value for conservation, has not been cultivated widely, many forms of a commercial product, species prioritized by the Ministry of Health, chemical and nutritional contents), three species have the highest potential to be developed, i.e. Cinnamomum burmanni, Morinda citrifolia, and Moringa oleifera. These three species are related to medicinal substances used to treat heart problems, hypertension, and diabetes which is a group of deadly non-communicable diseases, and are also used to treat diarrhea and liver, two dangerous communicable diseases.

\section{The commercial prospects for the three species Cinnamomum burmanni}

The first species is Cinnamomum burmanni or cinnamon. Indonesia is still the main exporter of cinnamon (Sa'diyah and Darwanto 2020). Until 2015, Indonesia supplied up to $45 \%$ of the world's cinnamon. The price of cinnamon varies, in the form of powder is from IDR 55,000 to 70,000 per $\mathrm{kg}$, while in the form of dry bark is from IDR 40,000 to 56,000 , and the form of cinnamon oil ranges from IDR 29,000 to 50,000 per $10 \mathrm{ml}$ (Bappebti 2020). The last recorded production of cinnamon from smallholder plantations in 2018 was 83.73 thousand tons (Humaira and Rochdiani 2021). Nationally, cinnamon is the third source of foreign exchange after pepper and nutmeg from the plantation sector. However, currently, the production of cinnamon is very poor due to the decline in production. This is the result of the harvest system which tends to clear-cutting and decreasing planted-land due to land conversion.

Researchers have revealed the potential of cinnamon as a natural medicine to treat various diseases, including its potential to fight Covid 19 (Kulkarni et al. 2020), and diarrhea (Kumar et al. 2019). The main chemical content of essential oil from cinnamon is Cinnamaldehyde (Fajar et al. 2019), amounting to $83.65 \%$ (Tokan et al. 2019). The components of these essential oils have antibacterial activity against Escherichia coli and Staphylococcus aureus (Parisa et al. 2019), which are the causes of diarrhea. Cinnamaldehyde has the potential to be developed as an antibiotic to treat diarrhea (Tokan et al. 2019). Therefore, the development of cinnamon plant cultivation needs to be more encouraged.

Table 4. Ten species of forest medicinal plants that are highly valuable for economy and conservation efforts

\begin{tabular}{lclc}
\hline Species names & $\begin{array}{c}\text { Ranking of } \\
\text { recommended } \\
\text { cultivation }\end{array}$ & Form of commercial product (drug) & $\begin{array}{c}\text { Ministry of } \\
\text { Health } \\
\text { priority }\end{array}$ \\
\hline Moringa oleifera Lam. & 1 & $4,6,7,8,14,15,16,18,19,20,21,22,23,24$, \\
& & $25,26,27,28,30,31,33,35,37,38$ \\
Aleurites moluccanus (L.) Willd. & 4 & $4,11,23,24,25$ \\
Morinda citrifolia L. & 6 & $1,7,8,9,10,11,14,15,16,17,29,31,34,36$ \\
Cinnamomum burmanni (Nees \& T.Nees) Blume & 9 & $2,6,8,11,12,16,18,32$ \\
Artocarpus altilis (Parkinson ex F.A.Zorn) Fosberg & 11 & $6,7,8,11,14,15,30$ \\
Guazuma ulmifolia Lamk. & 24 & $1,2,6,8,14,15,18,30,34$ \\
Elaeocarpus grandiflorus Sm. & 44 & $1,3,9,11$ \\
Pometia pinnata J.R.Forst. \& G.Forst. & 55 & 7,10 \\
Schleichera oleosa (Lour.) Merr. & 57 & 4,7 \\
Pterocarpus indicus Willd & 59 & 8,13 \\
\hline Nin
\end{tabular}

Notes: Forms of commercial products (drug) based on survey in ten drug/herbal stores, and ten online shops, i.e. 1. Mix (liquid extract), 2. Mix (capsules), 3. Mix (curd/dry), 4. Oil (seeds), 5. Oil (bark), 6. Dried leaf simplicia, 7. Fresh leaf simplicia, 8. Leaf powder/flour simplicia, 9. Dried fruit simplicia, 10. Fresh fruit simplicia, 11. Powdered fruit/seed simplicia, 12. Dried bark/wood simplicia, 13. Fresh bark/wood simplicia, 14. Brewed tea, 15. Tea bag, 16. Syrup/liquid extract, 17. Jus, 18 Wedang/health drink, 19. Chocolate, 20. Coffee, 21. Stick, 22. Chips, 23. Soap, 24. Shampoo, 25. Cream, 26. Conditioner, 27. Masker, 28. Gel, 29. Serum, 30. Capsules (leaf extract), 31. Capsules (fruit/seed extract), 32. Capsules (bark extract), 33. Caplet, 34. Tablets, 35. Herbal drops, 36. Vinegar, 37. Noodle, 38. Crackers. 
Table 5. Medicinal uses, chemical and nutritional contents of ten high-value medicinal plants

\begin{tabular}{|c|c|c|c|}
\hline Species names & Medicinal uses & Chemical contents & Nutritional contents \\
\hline Aleurites moluccanus (L.) Willd. & $\begin{array}{l}\text { Cardiovascular, anemia, } \\
\text { cholesterol, hypertension, } \\
\text { diabetes }\end{array}$ & $\begin{array}{l}\text { Fruit: Oleic acid, Linoleic acid, } \\
\text { Linolenic acid }\end{array}$ & $\begin{array}{l}\text { Fruit: Carbohydrates, fats, beta- } \\
\text { carotene, niacin, protein, Vitamins } \\
\text { A, B1, B2, C, and minerals Na, P, } \\
\mathrm{K}, \mathrm{Ca}, \mathrm{Zn}, \mathrm{Cu}\end{array}$ \\
\hline $\begin{array}{l}\text { Artocarpus altilis (Parkinson ex } \\
\text { F.A.Zorn) Fosberg }\end{array}$ & Hypertension, diabetes & $\begin{array}{l}\text { Fruit: flavonoids, saponins, and } \\
\text { polyphenols; Leaves: } \\
\text { flavonoids, steroids, tannins, } \\
\text { phenolic, and anthraquinone }\end{array}$ & $\begin{array}{l}\text { Fruits: Carbohydrates, protein, } \\
\text { vitamins } \mathrm{B}, \mathrm{C}, \mathrm{E}, \text { beta-carotene, } \\
\text { folate, K, Fe, Ca, P; Leaves: amino } \\
\text { acids, omega } 3 \text {, omega } 6\end{array}$ \\
\hline $\begin{array}{l}\text { Cinnamomum burmanni (Nees \& } \\
\text { T.Nees) Blume }\end{array}$ & $\begin{array}{l}\text { Diabetes, heart problems, } \\
\text { Alzheimer's, cholesterol }\end{array}$ & $\begin{array}{l}\text { Bark: cinnamil } \\
\text { cinnamaldehyde, acetate, } \\
\text { eugenol, caryophyllene, } \\
\text { linalool, cineol, prosianidin }\end{array}$ & $\begin{array}{l}\text { Bark: Protein, fat, pectin, } \\
\text { polysaccharides, cinnamic acid and } \\
\text { phenolic acid }\end{array}$ \\
\hline Elaeocarpus grandiflorus $\mathrm{Sm}$. & Diuretic & $\begin{array}{l}\text { Leaves, fruit, stem: saponins, } \\
\text { flavonoids, polyphenols and } \\
\text { tannins; Seeds: alkaloids, } \\
\text { tannins and flavonoids }\end{array}$ & $\begin{array}{l}\text { Seeds: glycosides, } \mathrm{P}, \mathrm{Mn}, \mathrm{Ca}, \mathrm{Al} \text {, } \\
\mathrm{Mg}, \mathrm{Fe}, \mathrm{Ni}, \mathrm{Cu}\end{array}$ \\
\hline Guazuma ulmifolia Lamk. & $\begin{array}{l}\text { Diabetes, hypertension, } \\
\text { boils, hair growth, } \\
\text { slimming }\end{array}$ & $\begin{array}{l}\text { Leaves: flavonoids, steroids, } \\
\text { tannins }\end{array}$ & Leaves:, fats, proteins, \\
\hline Morinda citrifolia $\mathrm{L}$. & $\begin{array}{l}\text { Heart disorders, } \\
\text { cholesterol, hypertension, } \\
\text { diabetes, increase body } \\
\text { immunity }\end{array}$ & $\begin{array}{l}\text { Fruit: morindadiol, morindin, } \\
\text { alkaloids, anthraquinone, } \\
\text { flavonoids, glucose (b- } \\
\text { Dglucopyranose), indoles, } \\
\text { purines, and b-sitosterol }\end{array}$ & $\begin{array}{l}\text { Fruit: Carbohydrates, protein, } \\
\text { Vitamins A, C, E, minerals (K, S, } \\
\text { Ca, P, Se), and amino acids }\end{array}$ \\
\hline Moringa oleifera Lam. & $\begin{array}{l}\text { Hypertension, arthritis, } \\
\text { swelling, skin diseases, } \\
\text { diabetes }\end{array}$ & $\begin{array}{l}\text { Leaves: lutein, } \beta \text {-carotene, } \\
\text { polyprenol, } \beta \text {-sitosterol, } \\
\text { triacylglycerols, fatty acids, } \\
\text { and hydrocarbons }\end{array}$ & $\begin{array}{l}\text { Leaves: Chlorophyll a and b, } \\
\text { vitamin C, carotene, protein, amino } \\
\text { acids and minerals }\end{array}$ \\
\hline $\begin{array}{l}\text { Pometia pinnata J.R.Forst. \& } \\
\text { G.Forst. }\end{array}$ & $\begin{array}{l}\text { Hypertension, dysentery, } \\
\text { gynecological }\end{array}$ & Fruit: phenolics and tannins & Fruit: Vitamins C, E, and minerals. \\
\hline Pterocarpus indicus Willd & $\begin{array}{l}\text { Menstruation, pneumonia } \\
\text { and injuries }\end{array}$ & $\begin{array}{l}\text { Bark: terpenoids, steroids, } \\
\text { halfordinol and Butylated } \\
\text { hydroxytoluene; leaf: } \\
\text { flavonoids. Quercetin }\end{array}$ & Leaves: protein \\
\hline Schleichera oleosa (Lour.) Merr. & $\begin{array}{l}\text { Eczema, scabies, ulcers, } \\
\text { inflammation of the ears }\end{array}$ & $\begin{array}{l}\text { Leaves: polyphenols, } \\
\text { flavonoids, alkaloids, tannins, } \\
\text { phenols, and steroids }\end{array}$ & Fruit: Fat, protein, minerals $(\mathrm{Ca}, \mathrm{P})$ \\
\hline
\end{tabular}

Sources: market survey and literature study (Al-Dhubiab 2012; Ramakhrisna et al. 2014; Ragasa et al. 2015; Assi et al. 2017; Goswami et al. 2017; Irawan et al. 2017)

\section{Bioprospection value}

The older cinnamon tree contains higher essential oil content. Cinnamon trees aged 20 years have an essential oil content of 5.8\% (Tokan et al. 2019). According to Fajar et al. (2019), the productivity of essential oils is estimated at $336 \mathrm{~kg} / \mathrm{ha}$ (5 years old), $577 \mathrm{~kg} / \mathrm{ha}$ (12 years old), and 387 $\mathrm{kg} / \mathrm{ha}$ (20 years old). The prediction of the weight of cinnamon bark in one tree at the Bogor Botanical Gardens (62 years old) is $22.5 \mathrm{~kg}$ (Hidayat et al. 2021). The essential oil content is estimated at $1.305 \mathrm{~kg}(5.8 \% \times 22.5)$ and the cinnamaldehyde content is $1.09 \mathrm{~kg}(83.65 \% \mathrm{x}$ $1.305 \mathrm{~kg}$ ). The type of antibiotic to treat diarrhea caused by E. coli is cotrimoxazole, which is sold at IDR 2,318 per tablet. For adults, the dose of this antibiotic is two tablets to be taken two times a day, for five days. If cinnamaldehyde is equalized with the antibiotic cotrimoxazole $960 \mathrm{mg}$, it can produce $1,135.42$ tablets per tree $(1,090,000 \mathrm{mg}$ : 960 $\mathrm{mg}$ ). Nationally, it takes $1,431,496,600$ tablets (2 tablets $\mathrm{x}$ 2 times $x 5$ days $x 7,157,483$ people) or the equivalent of
IDR 3,318,209,118,800 (IDR 2,318 x 1,431,496,600 tablets). In order to produce $1,431,496,600$ tablets, $1,260,763.95$ individual trees $(1,431,496,600$ tablets: $1,135.42$ tablets / tree) of cinnamon are needed per year.

\section{Morinda citrifolia}

The second species is Morinda citrifolia or noni. Noni has great potential as a functional drink ingredient in line with the increasing public awareness of the importance of maintaining health. The market for products of noni is generally worldwide, with the largest markets in North America, Mexico, Asia, and Australia. The worldwide market for these products was an estimated US\$ 400 million in 2002 (Nelson 2003). One of the discoveries of the active substance from Morinda citrifolia or noni, which is being widely researched, is scopoletin. The scopoletin in noni is important for health and has been known to lower blood pressure. Scopoletin is a coumarin group compound that has immunomodulatory activity (Aldi et al. 2015) and 
dilates narrowed blood vessels (Praja et al. 2018). Rumiyati et al. (2016) stated that the content of scopoletin in noni fruit plays an important role in lowering blood pressure. Therefore, plants that are rich in nutrients and have many benefits for health need to be promoted again to the public so they want to do cultivation. Research and development also need to be improved by both the government and the private sector.

\section{Bioprospection value}

Riskesdas (2018) study stated that the number of hypertension cases in Indonesia was 63,309,620 people, while the death rate due to hypertension was 427,218 people. Captopril is a group of ACE inhibitors that people with hypertension commonly use. The price of captopril at drugstores is IDR 150 per $25 \mathrm{mg}$ tablet. The maximum prescribes per month is 90 tablets with an initial dose of 23 times a day. An estimated Captopril for one year is $5,697,865,800$ tablets $(63,309,620$ people x 90 tablets / month) or equivalent of IDR 854,679,870,000 (IDR 150 per tablet x 5,697,865,800).

The noni production is $440 \mathrm{~kg} /$ tree/year, and from 2.12 $\mathrm{kg}$ of dried noni fruit pulp will be obtained $30.7 \mathrm{~g}$ of dichloromethane extract, and from $10.4 \mathrm{~g}$ of dichloromethane extract produces $500.25 \mathrm{mg}$ of powdered scopoletin (Aldi et al. 2015), so that in $2.12 \mathrm{~kg}$ of dry noni will be obtained $1,476.69 \mathrm{mg}((500.25 \mathrm{mg}$ x $30.7 \mathrm{~g}): 10.4$ $\mathrm{g}$ ) of scopoletin, meaning that in $1 \mathrm{~kg}$ of dry noni there is $696.55 \mathrm{mg}(1,476.69: 2.12)$ scopoletin. If per $\mathrm{kg}$ of dry noni is produced from $7 \mathrm{~kg}$ of wet fruit, then in 1 year (440 $\mathrm{kg}$ of noni fruit $=440 / 7 \mathrm{~kg}=62.85 \mathrm{~kg}$ of dry), it can produce $43,778.17 \quad \mathrm{mg} \quad(62.85 \quad \mathrm{x} \quad 696.55)$ of scopoletin/tree/year.

If the effectiveness of noni extract is comparable to that of captopril (Rumiyati et al. 2016), then 1,751,127 $(43,778,17: 25)$ tablets/tree/year for $25 \mathrm{mg}$ captopril can be produced. This is equivalent to the price of IDR 262,669.05 $(1,751,127$ tablets x IDR 150 per tablet) per individual tree. Thus each year, a total of $3,253,827.85(5,697,865,800$ : $1,751,127$ tablets) of individual noni trees will be needed or the equivalent of IDR $854,679,870,223(3,253,827.85 \times$ IDR 262,669.05).

\section{Moringa oleifera}

The third species is Moringa oleifera which has the potential to treat diabetes. WHO predicts an increase in the number of people with Diabetes Mellitus (DM) in Indonesia from 8.4 million in 2000 to around 21.3 million in 2030 (Rudijanto et al. 2015). Indonesia is in the 4th position with the highest number of diabetics after India, China, and the United States. Based on Riskesdas (2018) results, $74.8 \%$ of diabetics used oral drugs and $25.29 \%$ of them took traditional medicines. One of the traditional medicines used is a mixture of Moringa oleifera leaves. Moringa leaf extract is non-toxic and safe to use as an herbal treatment (Nararya et al. 2015). There were 59 bioactive compounds from Moringa leaf extract, including amino and organic acids, nucleosides, glucosinolates, lignans, phenolic acids, and flavonoids (Borgonovo et al. 2020). Some studies have shown that moringa can help lower blood sugar levels. Scientists believe this effect is caused by plant compounds such as 4-[(-1rhamnosyloxy)benzyl]isothiocyanate. Jaiswal et al. (2013) proved that the active compound of Moringa leaves is more effective and much safer in reducing blood sugar levels compared to the chemical drug glipizide, a sulfonylurea class of oral antihyperglycemic drugs. The commercial potential of Moringa leaves is very promising so that the plant has a great opportunity to be cultivated.

\section{Bioprospection value}

In terms of drug equivalence, one of the most frequently used DM drugs is Glucotrol, a sulfonylurea group oral anti-diabetes drug with a glipizide composition of $10 \mathrm{mg}$. This product has a packaging of 30 tablets at a price of IDR 8,837 / tablet. The recommended dosage by Perkeni (Rudijanto et al. 2016) is $5-20 \mathrm{mg}$ per day (2 tablets). If it is predicted that 21.3 million sufferers in 2030 , and $15,932,400(74.8 \%)$ of them use oral drugs, then at least $31,864,800(2 \times 15,932,400)$ tablets are needed per day or $11,630,652,000$ tablets $(31,864,800 \times 365$ days $)$ per year is equivalent to IDR 102,780,071,724,000 (11,630,652,000 tablets $\mathrm{x}$ IDR 8,837 / tablet). The total weight of glipizide required per year is $110,630,652 \mathrm{~kg}$ $(11,630,652,000$ tablets $\times 10 \mathrm{mg}=110,630,652,000 \mathrm{mg}=$ $110,630,652 \mathrm{~kg})$. If glipizide was equated with isothiocyanates, it would require $6,664,497.108 \mathrm{~kg}$ $((110,630,652 \times 100): 1.66)$ of Moringa leaves. If it is predicted that one Moringa tree will produce $1.5 \mathrm{~kg}$ of leaves, it will require 4,442,998 $(6,664,497,108: 1.5)$ individual moringa trees per year.

To conclude, 59 species of NTFPs are used by 28 ethnic groups and have been produced in many drug and health supplements. All of these plant species need the attention of many parties to maintain their existence and increase their added value. However, based on cultivation recommendations, value for conservation, limited cultivation, many forms of a commercial product, priorities of the Ministry of Health, medicinal uses, and their phytochemical and nutritional contents, three species have the highest potential for immediate cultivation and development of their use, namely Cinnamomum burmanni, Morinda citrifolia, and Moringa oleifera. These three species, apart from being used traditionally by some ethnic groups in Indonesia, based on the potential for bioprospection, thousands of individual trees are still needed to produce compounds needed as commercial medicinal ingredients.

\section{ACKNOWLEDGEMENTS}

The first author is very grateful to the researchers who participated as respondents and discussion partners in this study, namely Prof. Johan Iskandar, Prof. Dyah Iswantini, Dr. Dewi Sukma, Dr. Wawan Sujarwo, Epina Cornely, Susi Purwiyanti, Dr. Ema Damayanti, Mercy Bientri Yunindanova, Nur Laela, and Solikin. Special thanks also to Sri Astutik and Ria Cahyaningsih for data sharing. 


\section{REFERENCES}

BAPPEBTI (Badan Pengawas Perdagangan Berjangka Komoditi). 2020 Analisis Harga Kayu Manis Bulan Juni 2020. http://bappebti.go.id/resources/docs/info. [Indonesian]

BPS (Badan Pusat Statistik). 2020. Statistik Indonesia 2020. Subdirektorat Publikasi dan Kompilasi Statistik. Jakarta: Badan Pusat Statistik. [Indonesian]

Al-Dhubiab BE. 2012. Pharmaceutical applications and phytochemical profile of Cinnamomum burmannii. Pharmacogn Rev 6 (12): 125 131. DOI: $10.4103 / 0973-7847.99946$

Aldi Y, Yuliandra Y, Nasrul E, Yanwirasti, Handayani D, Bakhtiar A. 2015. Decreased interleukin-4 level of type I hypersensitive mice using scopoletin isolated from noni fruit (Morinda citrifolia L.). Res J Pharm Biol Chem Sci 6 (4):1823-1829.

Assi RA, Darwis Y, Abdulbaqi IM, Khan AA, Vuanghao L, Laghari MH. 2017. Morinda citrifolia (Noni): A comprehensive review on it industrial uses, pharmacological activities, and clinical trials. Arab J Chem 10: 691-707. DOI: 10.1016/j.arabjc.2015.06.018.

Astutik S, Pretzsch J, Kimengs JN. 2019. Asian medicinal plants' production and utilization potentials: a review. Sustainability 11:5483. DOI: $10.3390 / \mathrm{su} 11195483$.

Borgonovo G, De Petrocellis L, Moriello AS, Bertoli S, Leone A, Battezzati A, Mazzini S, Bassoli A. 2020. Moringin, A stable Isothiocyanate from Moringa oleifera, activates the somatosensory and pain receptor TRPA1 channel In vitro. Molecules 25: 976-988. DOI: $10.3390 /$ molecules25040976.

Cahyaningsih R, Brehm JM, Maxted N. 2021. Gap analysis of Indonesian priority medicinal plant species as part of their conservation planning. Glob Ecol Conserv 26: 1-11. . DOI: 10.1016/j.gecco.2021.e01459.

Chapman K, Chomchalow N. 2005. Production of medicinal plants in Asia. Acta Hortic. 679: 45-59. DOI: 10.17660/ActaHortic.2005.679.6.

Chen SL, Yu H, Luo HM, Wu Q, Li CF, Steinmetz A. 2016. Conservation and sustainable use of medicinal plants: problems, progress, and prospects. Chin Med 11(37):1-10. DOI: 10.1186/s13020-016-0108-7.

El-shabasy A. 2017. Problems of medicinal plant in Jazan region and solutions. Asian J Med Health Res 2 (1): 8-10. . DOI: 10.9734/ajmah.

Fadhil R, Nurba D. 2019. Comparison of Gayo Arabica coffee taste sensory scoring system between Eckenrode and Fuzzy-Eckenrode methods. ICATES 2019. IOP Conf Ser Earth Environ Sci 365: 012040. DOI: $10.1088 / 1755-1315 / 365 / 1 / 012040$

Fajar A, Ammar GA, Hamzah M, Manurung R, Abduh MY. 2019. Effect of tree age on the yield, productivity, and chemical composition of essential oil from Cinnamomum burmannii. Curr Res Biosci Biotechnol 1 (1): 17-22. DOI: 10.5614/crbb.2019.1.1.

Goswami S, Singh RP. 2017. Ayurvedic, phytochemical and pharmacological review of Schleichera oleosa (Lour.) Oken: A traditional plant with enormous biological activity. World J Pharm Res 6 (10): 295-309. DOI: 10.20959/wjpr201710-9370.

Hidayat RS, Cahyaningsih R. 2017. Useful plants from Wolomeze Protected Forest, Ngada District, Flores, East Nusa Tenggara. Pros Sem Nas Masy Biodiv Indon 3 (1): 56-61. DOI: 10.13057/psnmbi/m030110.

Hidayat S, Zuhud EAM, Widyatmoko D, Bahruni. 2021. Assessing the conservation value of medicinal plant collections in Bogor Botanic Gardens, Indonesia. Biodiversitas 22 (2): 691-701. DOI: 10.13057/biodiv/d220221.

Hidayat S. 2017. The use by local communities of plants from Sesaot Protected Forest, West Nusa Tenggara, Indonesia. Biodiversitas 18 (1): 238-247. DOI: $10.13057 /$ biodiv/d180130.

Humaira FA, Rochdiani D. 2021. Faktor-faktor yang mempengaruhi volume ekspor kayu manis Indonesia. Mimbar Agribisnis 7 (1): 437 449. DOI: $10.25157 /$ ma.v7i1.4675.

Irawan C, Hanafi, Sulistiawaty L, Rochaeni H. 2017. Phytochemistry and total phenolic content of methanol extract of Pometia pinata J.R. Forst. \& G. Forst. fruit flesh from Papua, Indonesia. Trop Plant Res 4 (3): 401-404. DOI: 10.22271/tpr.2017.v4.i3.053.

Ismail AY, Kusmana C, Sudiana E, Widodo P. 2019. Population and stand structure of Cinnamomum sintoc in the Low Land Forest of Mount Ciremai National Park, West Java, Indonesia. Biodiversitas 20 (4): 1042-1047. DOI: 10.13057/biodiv/d200415

Jaiswal D, Rai PK, Mehta S, Chatterji S, Shukla S, Rai DK, Sharma G, Sharma B, Khair S, Geeta G. 2013. Role of Moringa oleifera in regulation of diabetes-induced oxidative stress. Asian Pac J Trop Med 2013: 426-432. DOI: 10.1016/S1995-7645(13)60068-1.
Kadam ST, Pawar AD. 2020. Conservation of medicinal plants: a review. Intl Ayurvedic Med J: 3890-3895. DOI: 10.46607/iamj0807112020.

Krishnakumar NM, Latha PG, Suja SR, Rajasekharan S. 2015. A Review on the ethnomedicinal, therapeutic and nutraceutical importance of 'Noni' (Morinda citrifolia L.). Intl J Med Plants Nat Prod 1 (3): 1-14. DOI: 10.20431

Kulkarni SA, Nagarajan SK, Ramesh V, Palaniyandi V, Selvam SP, Madhavan T. 2020. Computational evaluation of major components from plant essential oils as potent inhibitors of SARS-CoV-2 spike protein. J Mol Struct 1221: 128823. DOI: 10.1016/j.molstruc.2020.128823.

Kumar S, Kumari R, Mishra S.2019. Pharmacological properties and their medicinal uses of Cinnamomum: a review. J Pharm Pharmacol 71: 1735-1761. DOI: 10.1111/jphp.13173.

Kuniyal CP, Kuniyal PC, Butola JS, Sundriyal RC. 2013. Trends in the marketing of some important medicinal plants in Uttarakhand, India. Intl J Biodivers Sci Ecosyst Serv Manag 9 (4): 324-329. DOI: 10.1080/21513732.2013.819531.

Malik AA, Ahmad J, Abdin MZ. 2013. Development of organic cultivation of medicinal plants in North India. Herba Polonica 59 (4): 2013: 97-107. DOI: 10.2478/hepo-2013-0027.

Nararya SA, Jularso E, Budhy TI. 2015. Uji toksisitas daun Kelor (Moringa oleifera) terhadap sel fibroblas gingiva menggunakan uji MTT assay. J Biosains Pascasarjana 17 (1):52-59. DOI: 10.20473/jbp.v17i1.2015.52-58.

Nelson SC. 2003. Morinda citrifolia L. Species profiles for Pacific Island Agroforestry. <www.agroforestry.net>

Nento F, Tueno NS. 2019. Faktor-faktor penghambat partisipasi masyarakat dalam pelaksanaan program reboisasi di Kecamatan Bulango Ulu Kabupaten Bone Bolango. Publik 6 (2): 106-114. DOI: DOI: $10.37606 /$ publik.v6i2.11.

Nugroho IA, Nurrochmat DR, Hardjanto. 2016. Commercialization of medicinal plants in Java Island, Indonesia. J Manajemen Hutan Tropika 22 (2): 114-125.

Parisa N, Islami RN, Amalia E, Mariana, Rasyid RSP. 2019. Antibacterial activity of cinnamon extract (Cinnamomum burmannii) against Staphylococcus aureus and Escherichia coli in vitro. Bioscientia Medicina 3 (2): 19-28. DOI: 10.32539/bsm.v3i2.85.

Praja RA, Pratiwi D, Nuraini. 2018. Studi penambatan molekuler senyawa Scopoletin dari buah mengkudu (Morinda citrifolia L.) pada enzim ACE sebagai antihipertensi. Farmagazine 5 (1): 40-47. DOI: 10.47653/farm.v5i1.91

Ragasa CY, Medecilo MP, Shen CC. 2015. Chemical constituents of Moringa oleifera Lam. leaves. Der Pharma Chemica 7 (7): 395-399.

Rahayuningsih SR, Safitri R, Andayaningsih P. 2016. Potency of probiotic bacteria from noni fruit (Morinda citrifolia L.) as anti-helicobacter pylori agent. AIP Conf Proc 1744: 020055. DOI: 10.1063/1.4953529.

Riptanti EW, Qonita RA, Fajarningsih RU. 2018. The competitiveness of medicinal plants in Central Java, Indonesia. IOP Conf Ser Earth Environ Sci 142: 012018. DOI: 10.1088/1755-1315/142/1/012018.

Rudijanto A, Yuwono A, Shahab A, Manaf A, Pramono B, Lindarto D, Purnamasari D, Sanusi H, Zufry H, Novida H, Suastika K, Sucipto KW, Sasiarini L, Dwipayana MP, Saraswati MR, Soetedjo NN, Soewondo P, Soelistijo SA, Sugiarto, Langi YA. 2016. Konsensus pengelolaan dan pencegahan diabetes melitus tipe 2 di Indonesia 2015. Pengurus Besar Perkumpulan Endokrinologi Indonesia (PB PERKENI), Jakarta. [Indonesian]

Rumiyati, Hakim AR, Winarti AD, Septia DN. 2016. Antihypertensive testing of combination of Apium graveolans L., Orthosiphon stamineus Benth., and Morinda citrifolia L. extract. on normotensive and hypertensive Sprague Dawley rats. J Tradit Med 21 (3): 149-156. DOI: 10.22146/tradmedj.17321

Sa'diyah PFI, Darwanto DH. 2020. Indonesian Cinnamon competitiveness and competitor countries in international market. Agraris 6 (2): 124125. DOI: 10.18196/agr.6295

Schippmann U, Leaman D, Cunningham AB. 2006. A comparison of cultivation and wild collection of medicinal and aromatic plants under sustainability aspects. In: Bogers RJ, Craker LE, Lange D (eds.), Medicinal and Aromatic Plants. Springer, Netherlands.

Syamsiah, Hiola SF, Mu'nisa A, Jumadi O. 2016. Study on medicinal plants used by the Ethnic Mamuju in West Sulawesi, Indonesia. J Trop Crop Sci. 3(2): 42-48. DOI: 10.29244/jtcs.3.2.43-48.

Tokan MK, Ngurah BIGM, Saputra A. 2019. Aktivitas antibakteri Sinamaldehid yang diisolasi dari kulit batang kayu manis terhadap bakteri Staphylococcus aureus. Prosiding Seminar Nasional Pertanian 
ke 5, Fakultas Pertanian, Universitas Nusa Cendana 1 (5): 99-108. [Indonesian]

WHO's Global Health Estimates. 2020. The top 10 causes of death https://www.who.int/news-room/fact-sheets/detail/the-top-10causesof-death
Zakaria M, Hawa LC Djoyowasito G, 2019. Effect of $\mathrm{NaOH}$ concentration and immersion of ice water on physical and mechanical characteristics of candlenut seeds (Aleurites moluccana L Willd). Indon J Sci Technol 8 (1): 22-30. DOI: 10.21776/ub.igtj. 2019. 008.01.05. 